\section{Heat-treating 'Sharwil' Avocado for Cold Tolerance in Quarantine Cold Treatments}

\author{
Suzanne S. Sanxter, Kate A. Nishijima, and Harvey T. Chan, Jr. \\ U.S. Department of Agriculture, Agricultural Research Service, P.O. Box \\ 4459, Hilo, HI 96720
}

Additional index words. Persea americana, preconditioning, cold storage, chilling injury, fruit fly, heat stress, heat shock

\begin{abstract}
Chilling injury symptoms were reduced when 'Sharwil' avocados (Persea americana Mill.) were held at 37 to $38 \mathrm{C}$ for 17 to 18 hours and then air-cooled at $20 \mathrm{C}$ for 4 hours before storage at $1.1 \mathrm{C}$ for $\geq 14$ days. In contrast, nonheated fruit developed severe surface discoloration and pitting. Chilling injury symptoms were reduced further when the heated fruit were stored in perforated polyethylene bags during 1.1C storage. No treatment equaled or surpassed the quality of fruit in nontreated controls.
\end{abstract}

Recently, 'Sharwil' avocados have been determined to be a host, although a poor host, for the oriental fruit fly [Bactocera dorsalis (Hendel)] in Hawaii (N.J. Liquido, unpublished data). Avocados also are listed as a host for the melon fly [B. cucurbitae (Coquillett)] and the Mediterranean fruit fly [Ceratitis capitata (Weidemann)]. Therefore, for fruit to be exported from Hawaii, they first must be disinfested. Quarantine treatments of many fruit (other than avocado) have been established for Mediterranean fruit flies based on one of the following pulp temperature schedules: 10 days at $0 \mathrm{C}, 11$ days at $0.5 \mathrm{C}, 12$ days at $1.1 \mathrm{C}, 14$ days at $1.6 \mathrm{C}, 16$ days at $2.2 \mathrm{C}$ (Animal and Plant Health Inspection Service, 1993; Baker, 1939). However, avocado storage $<4$ to 7C causes chilling injury (CI) (McGregor, 1989). CI symptoms in avocado include discoloring of surface, graying of internal tissue, and browning of vascular tissue (Broadley, 1991). For cold treatments to become a plausible quarantine treatment for avocados, methods must be developed either to alleviate CI symptoms or increase CI tolerance (Chan, 1993).

'Sharwil' avocado, an Australian-developed cultivar (Sharpe, 1965), remains green when ripe. We report a method that induces tolerance to the low storage temperature $(<2.2 \mathrm{C}$, pulp) required for quarantine cold treatments in 'Sharwil'.

\footnotetext{
Received for publication 20 Dec. 1993. Accepted for publication 24 May 1994. We thank Nicanor Liquido and Linda Whitehand for their suggestions on statistical and data analysis. Reference to a company and (or) product named by the U.S. Dept. of Agriculture is only for purposes of information and does not imply approval or recommendation of the product to the exclusion of others that may also be suitable. The cost of publishing this paper was defrayed in part by the payment of page charges. Under postal regulations, this paper therefore must be hereby marked advertisement solely to indicate this fact.
}

\section{Materials and Methods}

Variables tested. Initial experiments (Apr. to July 1992) showed that avocados are sensitive to 46 to $49 \mathrm{C}$ water dips of $\geq 20 \mathrm{~min}$. Further preliminary tests showed that fruit, heat-treated for 17 to $18 \mathrm{~h}$ in air at 37 to $38 \mathrm{C}$ before storage for 14 days at $1.1 \pm 0.7 \mathrm{C}$ (except during defrost cycles when a maximum of 2.3C may occur, see Fig. 1), had reduced CI symptoms compared to nonheated fruit stored similarly (unpublished). Experiments were conducted in the following commercial season (Nov. 1992-Apr. 1993). 'Sharwil' avocados harvested from commercial orchards in the South Kona district on the Island of Hawaii were transported within 24 to 48 h to the U.S. Dept. of Agriculture, Agricultural Research Service, Tropical Fruit and Vegetable Research Laboratory, Hilo, Hawaii. Two hundred and forty to 340 fruit were used weekly in the various tests. Fruit free from defects were selected and separated into 10- to 40-fruit lots per treatment. Up to 40 fruit were packed into each vented fiberboard box and then heated in air at 37 to $38 \mathrm{C}$ for 17 to $18 \mathrm{~h}$ (treatments A through J), or held at $20 \mathrm{C}$ for 17 to $18 \mathrm{~h}$ (treatments K through O) (Table 1, section I). Air temperature $( \pm 2 \mathrm{C})$ and relative humidity $(\mathrm{RH})( \pm 5 \%)$ were monitored with hygrothermographs (Cole-Parmer Instrument Co., Chicago), which were calibrated before the first experiment. Heat treatments were applied in the presence $(+)$ (treatments $F$ through $J$ ) or absence (-) (treatments A through E) of ethylene scrubber sachets (9 to $10 \mathrm{~g}$ ) (Ethylene Control, Selma, Calif.). Ethylene scrubbers were tested with the intent of inhibiting ethylene-induced fruit ripening during prolonged storage.

Heat treatments were conducted in either of two incubators $\left(0.74 \mathrm{~m}^{3}\right)$ (Revco Scientific, Asheville, N.C., or Forma Scientific, Marietta, Ohio) to separate the + and - scrubber treatments. Fruit loads were typically 40 to 120 fruit per incubator. After heat treatment, fruit were removed from the fiberboard boxes and air-cooled (20C) for $4 \mathrm{~h}$ before cold storage for 14 days. Fruit were either bagged (+bag) (polyethylene bags, $51 \times 76 \mathrm{~cm}, 0.08 \mathrm{~mm}$ thick) (Shields Bag and Printing Co., Yakima, Wash.) or not bagged (-bag), placed in boxes, and then put in $1.1 \mathrm{C}$ storage. An ethylene scrubber was placed in some treatments (+bag, +scrubber or - bag, + scrubber). A second set of treatments (A, C, F, H, K, and M), which included perforated (hole $6 \mathrm{~mm}$ in diameter centered every $14 \mathrm{~cm}$ across each bag) bag treatments (+bag with holes, treatments E, J, and O) did not contain ethylene scrubbers. Ethylene scrubber treatments ( + or - ) were stored in separate $1.1 \mathrm{C}$ walk-in environmental rooms (Forma Scientific). Fifteen to 20 nontreated control fruit (treatment P) (Table 1, section III) for each experiment were held at $20 \mathrm{C}$ until ripe.

Further experiments were performed, adding extended storage time at $1.1 \mathrm{C}$ for 17 to 21 days. Only the most promising heat treatments were continued. Treatments generally were applied in the same manner as treatments for

Table 1. Effect of heat treatment (38C, 17 to $18 \mathrm{~h}$ ), with (+) or without (-) ethylene scrubber during heat treatment, 1.1C storage in polyethylene bag (+bag, -bag, or +bag with holes), and 1.1C storage with $(+)$ or without $(-)$ ethylene scrubbers on external (Ex.) and internal (In.) appearance of avocado fruit. Fruit were stored for 14 days (I) or 17 to 21 days (II) and then were ripened at room temperature (20C). Control fruit were held at room temperature (20C) until ripe (III). Data represent means of replications (reps.) consisting of 10 to 40 fruit per treatment.

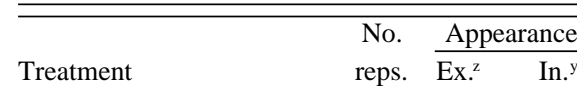

\section{Storage at $1.1 \mathrm{C}$ for 14 days}

Heat treatment, -scrubber

(B) +bag, +scrubber

(C) -bag, -scrubber

(D) -bag, +scrubber

(E) +bag with holes

Heat treatment, +scrubber

(F) +bag, -scrubber

(G) +bag, +scrubber

(H) -bag, -scrubber

(I) -bag, +scrubber

(J) +bag with holes

$\begin{array}{rll}9 & 2.5 & 25.5 \\ 11 & 2.7 & 32.0 \\ 5 & 2.7 & 59.7 \\ 8 & 2.7 & 68.5\end{array}$

No heat treatment, -scrubber

(K) +bag, -scrubber

(L) +bag, +scrubber

(M) -bag, -scrubber

(N) - bag, +scrubber

(O) +bag with holes

$\begin{array}{lll}7 & 2.9 & 75.1\end{array}$

II. Storage at $1.1 \mathrm{C}$ for 17 to 21 days

Heat treatment, -scrubber

$\begin{array}{llll}\left(C^{\prime}\right) \text {-bag, -scrubber } & 8 & 2.9 & 56.7\end{array}$

(D') -bag,+scrubber $\quad 5 \quad 2.9 \quad 56.7$

$\begin{array}{llll}\text { (E') +bag with holes } & 8 & 3.3 & 53.1\end{array}$

Heat treatment, +scrubber

$\begin{array}{llll}\left(\mathrm{H}^{\prime}\right) \text {-bag, }- \text { scrubber } & 8 & 3.0 & 60.0\end{array}$

$\begin{array}{llll}\text { (I') }- \text { bag, +scrubber } & 5 & 2.9 & 65.0\end{array}$

$\begin{array}{llll}\left(\mathrm{J}^{\prime}\right) \text { +bag with holes } & 8 & 3.1 & 62.1\end{array}$

III. Storage at $20 \mathrm{C}$ until ripe (6 to 8 days)

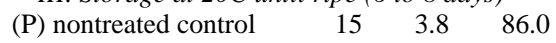

${ }^{2}$ External appearance was based on the following scale: 1 = unacceptable, 2 = marginally acceptable, $3=$ acceptable $/$ marketable, $4=$ good, $5=$ excellent. ypercentage of internally acceptable fruit. Internal acceptance was based on the lack of discoloration or disease. 


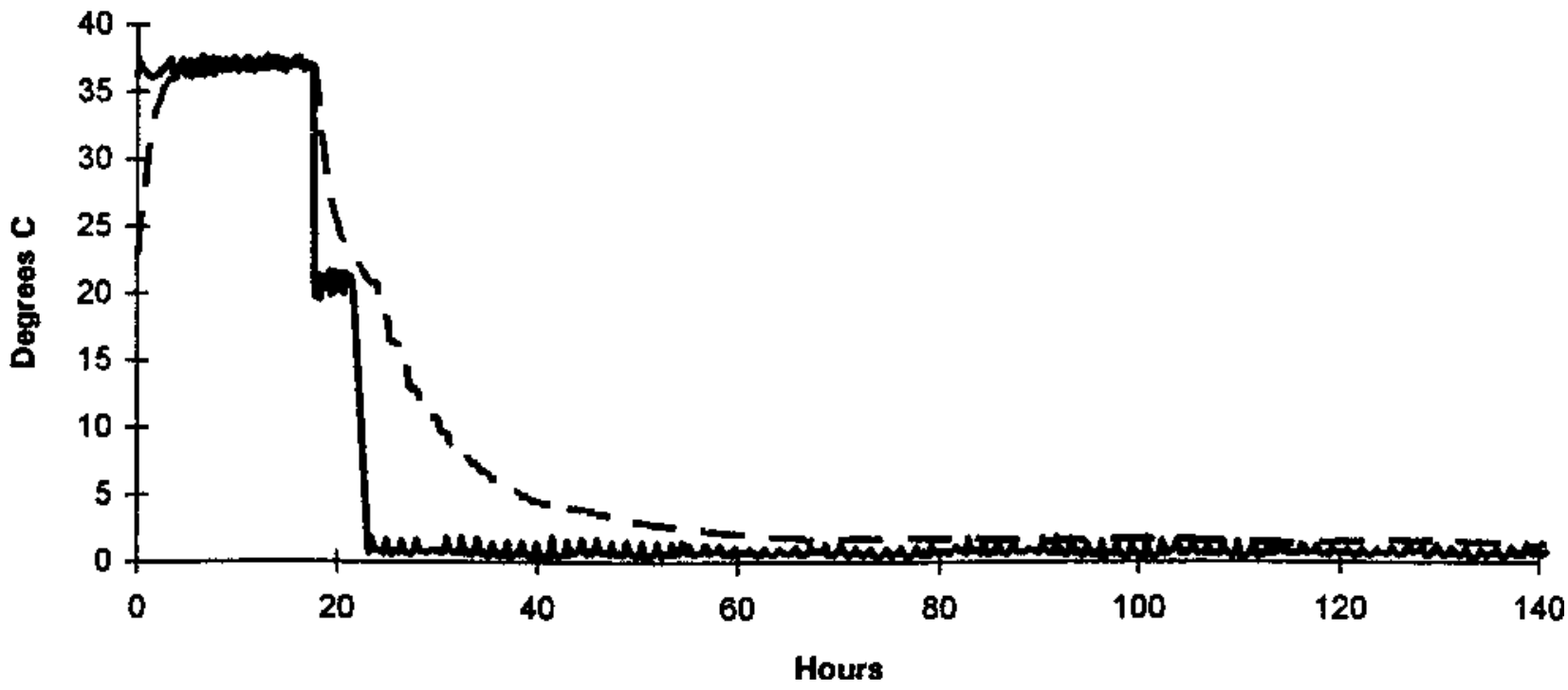

Fig. 1. Temperature profile of (-- - ) avocado fruit pulp at seed and ( - ) air during heat treatment (37 to $38 \mathrm{C}$ for 17 to $18 \mathrm{~h})$, air cooling ( $20 \mathrm{C}$ for $4 \mathrm{~h})$, and cold (1.1C) storage.

14-day storage, except that after pulp temperatures reached $\leq 2.2 \mathrm{C}$, fruit were placed in bags (when appropriate) and the 16 days of quarantine storage commenced. Seventeen- to 21day storage treatments were labeled $C^{\prime}, \mathrm{D}^{\prime}, \mathrm{E}^{\prime}$, $\mathrm{H}^{\prime}, \mathrm{I}^{\prime}$, and $\mathrm{J}^{\prime}$ (Table 1 , section II). Control fruit (P) also were used (Table 1, section III).

Temperatures of pulp at the seed surface of four fruit per test and of air $( \pm 0.3 \mathrm{C})$ were monitored with a polycorder (Omnidata International, Logan, Utah) using thermistors. RH was monitored with hygrothermographs.

Quality evaluation. Fruit were ripened at 20C and evaluated when fruit were edible. The number of days to reach eating ripeness was noted, and fruit appearance was evaluated. External appearance was rated on a scale of 1 to $5(1=$ unacceptable, $2=$ marginally acceptable, $3=$ acceptable $/$ marketable, $4=$ good, and $5=$ excellent fruit). The degree of surface discoloration, pitting, and disease were factors used to evaluate external quality. Fruit were cut in half distally, and internal appearance was evaluated. Fruit were unacceptable internally if pulp was lumpy, if vascular tissue was stringy, or if either structure was more than slightly discolored or diseased. Data were analyzed using the general linear models procedure (SAS Institute, 1988) for unbalanced design for main and interactive effects of heat treatment, ethylene scrubbers during heat or $1.1 \mathrm{C}$ storage, and bags and also for differences among treatments and replicates.

\section{Results and Discussion}

Pulp temperature reached $37 \mathrm{C}$ after $5 \mathrm{~h}$ of heat treatment (Fig. 1). After $4 \mathrm{~h}$ of cooling at room temperature, pulp temperatures were 22 to $23 \mathrm{C}$. After 1 to 2 days of storage at $1.1 \mathrm{C}$, pulp temperatures were $\leq 2.2 \mathrm{C}$. $\mathrm{RH}$ inside the incubators rose from an initial $30 \%$ to $98 \%$ by the end of the heat treatment. The increase in humidity rose from the fruit; however, desiccation was not apparent at quality evaluation.

Differences among treatments and replica-

Table 2. Two-way analysis of variance of external (Ex.) and internal (In.) appearance of avocado fruit stored at $1.1 \mathrm{C}$ for 14 days or 17 to 21 days and then were ripened at room temperature (20C).

\begin{tabular}{|c|c|c|c|c|c|c|}
\hline & & & Duratic & ige & & \\
\hline & & 14 & & & $17-2$ & \\
\hline & & Mean sc & & & Mean sc & \\
\hline & & Appear & & & Appear & \\
\hline & df & Ex. & In. & df & Ex. & In. \\
\hline Treatment & 14 & $1.0123^{* * *}$ & $3385.1^{* * * *}$ & 5 & 0.1608 & 113.71 \\
\hline Replicate & 12 & $0.7734^{* * * *}$ & $3288.8^{* * * *}$ & 7 & $0.2909^{*}$ & $2379.0^{* * * * *}$ \\
\hline
\end{tabular}

${ }^{*, * * *}$ Significant at $P \leq 0.05$ or 0.001 .

tions for avocados stored at $1.1 \mathrm{C}$ for 14 days were significant $(P \leq 0.001)$ for external and internal quality (Table 2). Replication to replication variation (block effect) could be due to differences among growers' cultural practices and orchard locations. Factorial analysis indicated external and internal quality were significantly $(P \leq 0.01)$ better in fruit heated at 37 to $38 \mathrm{C}$ for 17 to $18 \mathrm{~h}$ than in nonheated fruit (Table 3). For example, nonheated fruit stored at $1.1 \mathrm{C}$ without bags and with or without ethylene scrubbers (-bags, + or -ethylene scrubbers; $\mathrm{M}$ and $\mathrm{N}$ ) were rated about one unit lower in external appearance than heated fruit (C and D) (Table 1).

Avocado storage at $1.1 \mathrm{C}$ for 14 days in + bag treatments significantly affected $(P \leq$ 0.05 ) external and internal quality (Table 3 ). In nonheated avocados, fruit from + bag treatments were rated about one unit higher for external appearance ( $\mathrm{K}$ and $\mathrm{L}$ ) than those in -bag treatments ( $\mathrm{M}$ and $\mathrm{N}$ ) because the external CI symptoms of scalding and pitting were reduced. However, internal quality was lower in +bag treatments because of increased incidences of gray flesh or disease. In heated fruit, heat and +bag treatments interacted significantly $(P \leq 0.05)$ (Table 3$)$. External and internal qualities were lower for +bag than for -bag treatments (A, B, F, and G compared to $\mathrm{C}, \mathrm{D}, \mathrm{H}$, and I) (Table 1) due to increased incidences of gray flesh and stem-end and body rots.

Disease incidences were greatly reduced in the +bag with holes treatments. Fruit in such bags ( $\mathrm{E}$ and $\mathrm{J}$ ) had the highest external and internal quality of all treatments stored for 14 days (Table 1). The beneficial effect of using +bag with holes rather than +bag (without holes) may be due to decreased humidity, which was less conducive to microorganism growth.

Heated fruit stored at $1.1 \mathrm{C}$ for 17 to 21 days had significant $(P \leq 0.05)$ test-to-test variation (block effect); however, just as for 14 days storage, there were no significant differences among the six treatments $\left(\mathrm{C}^{\prime}, \mathrm{D}^{\prime}, \mathrm{E}^{\prime}, \mathrm{H}^{\prime}, \mathrm{I}^{\prime}\right.$, and $\mathbf{J}^{\prime}$ ) (Table 2). Bags with holes ( $\mathrm{E}^{\prime}$ and $\mathrm{J}^{\prime}$ ) again led to the highest mean external appearance ratings (3.25 and 3.08, respectively) (Table 1, section II). The lack of differences among treatments in extended cold storage was possibly due to the additional stresses placed on the fruit during the extra storage time.

Regardless of the duration of cold storage, using ethylene scrubbers during heat treatment or during cold storage, with or without the use of bags, did not significantly $(P>0.05)$ affect external or internal quality (Table 3 ). In addition, there was no treatment that equaled or surpassed the quality of nontreated control (P) fruit (Table 1, section III).

The number of days required for the fruit to ripen at $20 \mathrm{C}$ varied according to the treatment and the length of storage at 1.1C. Nonheated control fruit $(\mathrm{P})$ ripened in 7 days, and fruit stored for 14 days at $1.1 \mathrm{C}$, with or without heat 
Table 3. Factorial analysis of variance of heat treatment (38C, 17 to $18 \mathrm{~h}$ ), ethylene scrubber during heat treatment, storage in polyethylene bag (+bag, -bag, or bag+holes), and storage with scrubber in bag, on external (Ex.) and internal (In.) appearance of avocado fruit stored at $1.1 \mathrm{C}$ for 14 days.

\begin{tabular}{|c|c|c|c|}
\hline \multirow[b]{3}{*}{ Source } & \multirow[b]{3}{*}{$\mathrm{df}$} & \multirow{2}{*}{\multicolumn{2}{|c|}{$\begin{array}{c}\text { Mean square } \\
\text { Appearance } \\
\end{array}$}} \\
\hline & & & \\
\hline & & Ex. & In. \\
\hline \multicolumn{4}{|c|}{ Data set of treatments $(A, B, C, D, F, G, H, I)^{z}$} \\
\hline \multicolumn{4}{|c|}{ Scrubber during heat } \\
\hline Bag (+bag or -bag) & 1 & $0.9879^{*}$ & $22,105.7^{* * *}$ \\
\hline \multicolumn{4}{|l|}{ Scrubber in bag during } \\
\hline ScHeat $\times$ Bag & 1 & 0.4430 & 54.744 \\
\hline Bag & 1 & 0.0360 & 184.72 \\
\hline $\mathrm{Bag} \times \mathrm{ScBag}$ & 1 & 0.7311 & 217.92 \\
\hline \multicolumn{4}{|c|}{ Data set of treatments $(A, B, C, D, K, L, M, N)$} \\
\hline Heat treatment (Heat) & 1 & $4.9473^{* * *}$ & $3,186.3^{*}$ \\
\hline Bag (+bag or -bag) & 1 & $2.7813^{* * *}$ & $11,395.9^{* * *}$ \\
\hline \multicolumn{4}{|l|}{ Scrubber in bag } \\
\hline Heat $\times$ Bag & 1 & $3.6158^{* * * *}$ & 883.50 \\
\hline Heat $\times$ ScBag & 1 & 0.1603 & 214.43 \\
\hline $\mathrm{Bag} \times \mathrm{ScBag}$ & 1 & 0.0399 & 0.078 \\
\hline
\end{tabular}

Data set of treatments $(A, C, E, F, H, J)$

Scrubber during heat

$\begin{array}{lllr}\begin{array}{c}\text { treatment } \\ \text { Bag (+bag, -bag, or }\end{array} & 1 & 0.0838 & 1.2801 \\ \text { bag with holes) } & 2 & 1.6414^{* * *} & 12,459.9^{* * * *} \\ \text { ScHeat } \times \text { Bag } & 2 & 0.3652 & 194.94\end{array}$

Data set of treatments $(A, C, E, K, M, O)$

\begin{tabular}{|c|c|c|c|}
\hline Heat treatment & 1 & $2.3198^{* * *}$ & $1,045.9$ \\
\hline $\begin{array}{c}\text { Bag (+bag, -bag, or } \\
\text { bag with holes) }\end{array}$ & 2 & 0.7642 & $5,036.1^{* *}$ \\
\hline Heat $\times$ Bag & 2 & $1.0038^{*}$ & 939.53 \\
\hline
\end{tabular}

${ }^{2}$ Data represent means of replicates consisting of 10 to 40 fruit per treatment.

*, ${ }^{* *},{ }^{* * *}$ Mean square for main effect or interaction significant at $P \leq 0.05,0.01$, or 0.001 . treatment, ripened in $\approx 6$ days. Fruit held at $1.1 \mathrm{C}$ for 17 to 21 days ripened in 5 days (average).

Fruit quality can be maintained during a quarantine cold treatment for avocado by first treating the fruit with heat at 37 to $38 \mathrm{C}$ for 17 to $18 \mathrm{~h}$. McCollum et al. (1993) and Lurie and Klein (1991) reported similar results for inducing cold tolerance by heat stress for mango (Mangifera indica L.) and tomato (Lycopersicon esculentum Mill.), respectively. Similar work using the 'Hass' avocado is in progress in New Zealand (Woolf et al., 1993), Australia (Florissen et al., 1993), and California (M.L. Arpaia, personal communication). This heat treatment and cold storage for avocado could prove valuable in extending commodity transit times and, hence, create new markets. Additionally, fruit quality may be retained further by storing fruit in polyethylene bags with perforations during cold storage. Ethylene scrubbers in heat treatment or during cold storage did not improve external or internal quality.

Although tolerance to low temperatures can be induced in insects by heat, such as that reported for Drosophila melanogaster (Burton et al., 1988), preliminary efficacy experiments at this laboratory indicate that considerable insect kill resulted from the heat treatment regime alone (E.B. Jang, personal communication). Further efficacy work is needed to determine if shorter storage times at $1.1 \mathrm{C}$ are sufficient to provide quarantine security when combined with a heat pretreatment.

\section{Literature Cited}

Animal and Plant Health Inspection Service. 1994. T107(a): Cold treatment schedules for Ceratitis capitata (Medfly), p. 5.62. In: Plant protection and quarantine treatment manual.
U.S. Dept. of Agriculture, Hyattsville, Md. Baker, A.C. 1939. The basis for treatment of products where fruitflies are involved as a condition for entry into the United States. U.S. Dept. Agr. Circ. 551, Washington, D.C.

Broadley, R.H. 1991. Avocado pests and disorders. Queensland Dept. of Primary Industries, Brisbane, Australia.

Burton, V., H.K. Mitchell, P. Young, and N.S. Petersen. 1988. Heat shock protection against cold stress of Drosophila melanogaster. Mol. Cell Biol. 8(8):3550-3552.

Chan, H.T., Jr. 1993. Strategies for overcoming tissue damage caused by quarantine heat and cold treatments, p. 283-287. In: Proc. Australasian Postharvest Conf., Univ. of Queensland, Gatton College, Lawes, Australia, 20-24 Sept. 1993.

Florissen, P., B. McGlasson, J.Conroy, and P. Holford. 1993. The effect of 'heat-shock' treatment on chilling injury in avocados (Persea americana Mill), p. 145-147. In: Proc. Australasian Postharvest Conf., Univ. of Queensland, Gatton College, Lawes, Australia, 20-24 Sept. 1993.

Lurie, S. and J.D. Klein. 1991. Acquisition of low temperature tolerance in tomatoes by exposure to high-temperature stress. J. Amer. Soc. Hort. Sci. 116:1007-1012.

McCollum, T.G., S. D' Aquino, and R.E. McDonald. 1993. Heat treatment inhibits mango chilling injury. HortScience 28:197-198.

McGregor, B.M. 1989. Tropical products transport handbook. Agr. Hdbk. 668. U.S. Dept. of Agr., Washington, D.C. p. 78

SAS Institute, Inc. 1988. SAS/STAT user's guide. 6.03 ed. SAS Institute, Cary, N.C.

Sharpe, F.V. 1965. The Sharwil avocado comes from Redland Bay area. Queensland Fruit \&Vegetable Nwsl. 11:471.

Woolf, A.B., C.B. Watkins, I.B. Ferguson, and M. Lay-Yee. 1993. Dry heat treatments of avocado and the reduction of chilling injury during storage, p. 177. In: Proc. Australasian Postharvest Conf., Univ. of Queensland, Gatton College, Lawes, Australia, 20-24 Sept. 1993. (Abstr.) 